\title{
Editorial
}

\section{Oral medicine in Europe and the European Association of Oral Medicine}

\author{
Marco Carrozzo ${ }^{1,2}$ \\ 1 Professor of Oral Medicine, Dental School, Newcastle University, United Kingdom \\ 2 President of the European Association of Oral Medicine, United Kingdom
}

Oral Medicine (OM) is generally defined as the branch of dentistry related to the oral health care of patients suffering from chronic recurrent and medically related disorders of the mouth and maxillofacial region with their diagnosis and mostly non-surgical management. OM was originally called dental medicine and it is sometimes termed oral and maxillofacial medicine and, mainly in the Ibero-American world and in Southern Europe, also stomatology [1].

Scopes and definition of $O M$ are not the same everywhere and these differences are likely the result of cultural, economic, differences, heterogeneity of settings and health care systems. However, there is a broad agreement about clinical activities as $O M$ practice in mainly devoted to the diagnosis and management of oral mucosal lesions, salivary gland disorders, and oral manifestations of dermatologic, gastrointestinal, infectious diseases (such as but not restricted to HIV and HCV), and facial pain [2].

OM works closely with other Dental (mainly Oral Pathology, Oral Radiology, Periodontology, Geriatric Dentistry, Oral Surgery, Special Need Dentistry) and Medical (especially Oral and MaxilloFacial Surgery, Dermatology, Otorhinolaryngology, Gastroenterology, Ophthalmology, Rheumatology, Neurology) specialties.

OM has an active research component: just as an example and without any wish to be comprehensive, land marking discoveries published by OM colleagues include fields as Infectious diseases [3,4], Hepatology [5], Oncology [6], Rheumatology [7], and Pharmacology [8].

$O M$ is recognized as a specialty by Local Registering Authorities in Europe in Croatia, Israel and United Kingdom whereas OM training is a distinct field of study in Finland, Greece, Ireland, Italy, Spain, Sweden [2].

The European Association of Oral Medicine (EAOM) was founded 1998 in London by Professors Crispian Scully (United Kingdom) and Isaac van der Waal (Netherlands) along with Professors Sir David Mason, Tony Axéll (Scandinavia), Antonio Azul (Portugal), and Stephen Challacombe (United Kingdom) [1] and I am honoured to be the 10th President of the Society.
EAOM aims to improve clinical care in the field of $0 \mathrm{M}$ and to promote education and research in $\mathrm{OM}$ and also to inform governments and other official institutions of the significance of $0 \mathrm{M}$ for oral and systemic health. The latter is particularly relevant for a broader official recognition of OM in Europe and worldwide.

EAOM activities are not just limited to Europe and the Society has a truly international vocation and is willing to engage with any dentist and/or medical doctor who share an interest in $\mathrm{OM}$ regardless of the geographic and training background.

EAOM has, for example, a consistent number of fellows from USA, Japan, Brazil and Thailand.

We run increasingly successful biannual meetings. The next one will be held in September 2018 in Gothenburg, Sweden, jointly with the World Workshop of Oral Medicine and we will celebrate the 20th Anniversary of EAOM.

EAOM is also strongly committed to support young colleagues who are starting their career in $\mathrm{OM}$ through monetary competitive prizes and travel bursaries.

Kindly keep in touch through EAOM web-site (http://www. eaom.eu/) and/or feel free to contact myself or the EAOM secretary if you are thinking to join our big OM community or simply to gain more information about our activities and to discover the advantage to be an EAOM member.

\section{References}

1. Scully C, Miller CS, Aguirre Urizar JM, Alajbeg I, Almeida OP, Bagan JV et al. Oral medicine (stomatology) across the globe: birth, growth, and future. Oral Surg Oral Med Oral Pathol Oral Radiol 2016;121:149-157.

2. Bez C, Sklavounou A, Carrozzo M. Oral medicine in Europe: past, present and future. Br Dent J 2017. D0I: 10.1038/sj.bdj.2017.891.

3. De Souza YG, Greenspan D, Felton JR, Hartzog GA, Hammer M, Greenspan JS. Localization of Epstein-Barr virus DNA in the epithelial cells of oral hairy leukoplakia by in situ hybridization of tissue sections. N Engl J Med 1989;320:1559-1560. 
4. Maitland NJ, Cox MF, Lynas C, Prime SS, Meanwell CA, Scully C. Detection of human papillomavirus DNA in biopsies of human oral tissue. Br J Cancer 1987;56:245-250.

5. Carrozzo M, Quadri R, Latorre P, Pentenero S, Berytolusso G, Gandolfo S, Negro F. Molecular evidence that the hepatitis $C$ virus replicates in the oral mucosa. J Hepatol 2002;37:364-369.

6. King GN, Healy CM, Glover MT, Kwan JT, Williams DM, Leigh IM, Worthington HV, Thornhill MH et al. Increased prevalence of dysplastic and malignant lip lesions in renal-transplant recipients. N Engl J Med 1995;332:1052-1057.
7. Shiboski CH, Shiboski SC, Seror R et al. 2016 American College of Rheumatology/European League Against Rheumatism Classification Criteria for Primary Sjögren's syndrome: a consensus and datadriven methodology involving three international patient cohorts. Arthritis Rheumatol 2017;69:35-45.

8. Dayer MJ, Jones S, Prendergast B, Baddour LM, Lockhart PB, Thornhill MH. Incidence of infective endocarditis in England, 2000-13: a secular trend, interrupted time-series analysis. Lancet 2015;385:1219-1228. 